\title{
AKTSAR
}

ISSN 2622-5255 (online)

Volume 2 Nomor 1, Juni 2019, Halaman 109-120

ISSN 2622-2345 (cetak)

\section{Akuntansi Manajemen Syariah dan Konstruksi Sosial (Sebuah Studi Literatur)}

\author{
Fathul Aminudin Aziz \\ IAIN Purwokerto \\ aminazizcenter@iainpurwokerto.ac.id
}

\begin{abstract}
In the reality of life, management accounting has many variables related to social aspects through the basic assumptions of behavior by looking at the Islamic world. The purpose of this study is to make a construction of Islamic management accounting with the social aspects of Muslim behavior. This research is literature research. The principle used in this discussion is to "fix old things that are good and make new things that are better". Management accounting should ideally be built and practiced based on social values so that the information transmitted is also social. In the end, economic decisions are taken by top management and middle management based on social assessments that encourage the creation of economic and business realities that lead to prosperity in justice and prosperity.
\end{abstract}

Keywords: Management Accounting; Islamic Management Accounting; Social Aspect 


\begin{abstract}
ABSTRAK
Di dalam realita kehidupan, akuntansi manajemen memilik banyak variabel yang berhubungan dengan aspek sosial melalui identifikasi asumsi-asumsi dasar keperilakuan dengan melihat dunia Islam. Tujuan dari penelitian ini adalah membuat konstruksi akuntansi manajemen syariah dengan aspek sosial keperilakuan umat Islam. Penelitian ini merupakan penelitian literatur. Kaidah yang digunakan dalam pendekatan ini adalah "memelihara hal-hal lama yang bagus dan mengambil hal-hal baru yang lebih bagus". Akuntansi manajemen secara ideal harus dibangun dan dipraktikkan berdasarkan nilai sosial, sehingga informasi yang dipancarkan juga bernuansa sosial. Pada akhirnya keputusan-keputusan ekonomi yang diambil oleh top management maupun middle management berdasarkan atas nilai sosial yang mendorong terciptanya realitas ekonomi dan bisnis yang mengarah pada kesalehan sosial yang berkemakmuran dan berkeadilan.
\end{abstract}

Kata kunci: Akuntansi Manajemen; Akuntansi Manajemen Syariah; Aspek Sosial

\title{
PENDAHULUAN
}

Islam adalah agama yang kaffah (sempurna), berbagai aspek kehidupan dalam ajaranya membuat manusia memiliki hidup yang sempurna dan berarti. Salah satu aspek yang dapat meningkatkan makna hidup adalah ekonomi. Ekonomi adalah faktor penting yang memiliki tujuan untuk memenuhi kebutuhan dasar manusia. Para pakar ekonomi Islam mendefiniskan ekonomi dalam Islam sebagai ilmu yang mempelajari perilaku manusia dalam memenuhi kebutuhan hidupnya dengan tujuan memperoleh falah/kebahagiaan diri dan orang lain.

Ekonomi yang dalam bahasa Arab disebut al-Iqtishâd secara etimologi berarti pertengahan atau sederhana dalam produksi (intâj), (istihlâkî) dan menyimpan/saving (iddikhâr, pertengahan didalamnya termasuk dalam mengelola akuntansi dengan baik. Menurut Syaiful Bahri (2016) akuntansi merupakan seni pencatatan, penggolongan, pengikhtisaran, dan pelaporan atas suatu transaksi dengan cara sedemikian rupa, sistematis dari segi sisi, dan berdasarkan standar yang diakui umum. Oleh karena itu pihak dari luar perusahaan dapat mengetahui posisi keuangan perusahaan serta hasil operasi pada setiap waktu yang diperlukan sehingga dapat mengambil keputusan maupun pemilihan dari berbagai tindakan alternatif di bidang ekonomi.

Sejarah akuntansi manajemen sudah diperkenalkan sejak al-Quran diturunkan dalam bentuk lafad ijmali (universal), namun kajian-kajian islam lebih ditekankan pada ibadah mahdloh sehingga kajian "ilmu umum" sangat tertinggal, pernah mengalami kejayaan namun kemudian surut kembali. Umat Islam harus sadar bahwa 
akuntasi manajemen yang berasal dari komunitas kapitalis memiliki pola pikir barat bercirikan muatan materialistis dan individualistis yang potensial menimbulkan perilaku disfungsional, tanpa melihat aspek sosial. Didalam realita kehidupan, akuntansi manajemen memilik banyak variabel yang berhubungan dengan aspek sosial melalui identifikasi asumsi-asumsi dasar keperilakuan dengan melihat dunia Islam yang dapat digunkan untuk membangun akuntansi manajemen syariah. Kaidah yang digunakan dalam pendekatan ini adalah "memelihara hal-hal lama yang bagus dan mengambil hal-hal baru yang lebih bagus".

Penerapan kaidah ini menggunakan kaidah akuntansi manajemen konvensional yang baik dan menggali kembali dari dalil al-Quran dan al-Hadits. Untuk mendapatkan konsep baru yang lebih baik, kajian yang berkelanjutan terus dilakukan baik dari segi konsep pemikiran maupun penelitian, dengan dorongan dan kemauan yang kuat sebagai wujud jihad dalam ilmu akuntansi manajemen.

\section{TINJAUAN LITERATUR}

Akuntansi manajemen bermanfaat untuk memberikan informasi keuangan untuk melihat potret perusahaan dalam kacamata manajemen sebagai referensi dalam pengambilan keputusan yang tepat, dan mengevaluasi kinerja perusahaan dalam berbagai aspek antara lain perencanaan, pengorganisasian, pengarahan, dan pelaksanaan. Menurut Hariadi (2002) Akuntansi manajemen merupakan identifikasi, pengukuran, pengumpulan, analisis, pencatatan, interpretasi, dan pelaporan kejadian-kejadian ekonomi suatu badan usaha yang dimaksudkan agar manajemen dapat menjalankan fungsi perencanaan, pengendalian, dan pengambilan keputusan. Akuntansi manajemen dapat dipandang dari dua sudut akuntansi manajemen sebagai salah stau tipe akuntansi dan akuntansi manajemen sebagai salah satu tipe informasi. Sebagai salah satu tipe akuntansi, akuntansi manajemen merupakan suatu sistem pengolahan informasi keuangan yang digunakan untuk menghasilkan informasi keuangan bagi kepentingan pemakai intern organisasi. Sebagai salah satu tipe informasi akuntansi manajemen merupakan tipe informasi kuantitatif yang menggunakan uang sebagai satuan ukuran yang digunakan untuk membantu manajemen dalam pelaksanaan pengelolaan perusahaan. Dengan demikian akuntansi manajemen adalah informasi keuangan yang merupakan keluaran yang dihasilkan oleh tipe akuntansi manajemen, yang dimanfaatkan oleh pemakai intern organisasi (Mulyadi, 2001).

Menurut Aziz (2017) menyatakan bahwa manajemen dalam Islam lebih dekat dengan pengertian ruang, dan waktu niat, ikhtiar, dan tawakal, karena sesungguhnya dalam Islam niat adalah motivasi awal sebuah perbuatan terjadi, kemudian diimplementasikan dengan ikhtiar yang maksimal untuk mencapai tujuan yang ditetapkan dalam niat. Jadi yang paling utama dalam manajemen Islami adalah niat dan ikhtiar, sedangkan tujuanya diberikan Allah dalam bentuk tawakal.

Menurut Chartered Institute of Management Accountant (1994), akuntansi manajemen sebagai penyatuan bagian manajemen yang mencakup, penyajian dan penafsiran informasi yang digunakan untuk perumusan strategi, aktivitas perencanaan dan pengendalian, pembuatan keputusan, optimalisasi penggunaan sumber daya, pengungkapan kepada pemilik dan pihak luar, pengungkapan kepada 
pekerja, pengamanan asset guna menghasilkan informasi untuk pengguna internal, seperti manajer, eksekutif, dan pekerja.

Sedangkan akuntansi manajemen syariah merupakan fenomena praktik akuntansi yang berkembang dalam kehidupan sosial-ekonomi masyarakat Islam yang menerapkan prinsip syariah, Seiring dengan berkembangnya ekonomi Islam, maka semakin banyak lembaga perbankan yang menjalankan usahanya berdasarkan prinsip syariah, sehingga praktik akuntansi manajemen syariah perlu dikembangkan secara berkelanjutan yang berkaitan dengan aspek sosial, artikel ini membahas akuntansi manajemen syariah dan konstruksi sosial.

\section{METODE}

Jenis penelitian ini termasuk dalam penelitian kepustakaan (library research), penelitian kepustakaan menggunakan data-data atau bahan-bahan yang diperlukan dalam menyelesaikan penelitian yang berasal dari perpustakaan baik berupa buku, ensklopedi, kamus, jurnal, dokumen, majalah dan lain sebagainya (Sutrisno, 1990). Penelitian ini lebih banyak mengacu pada kepustakaan berupa kitab suci yaitu alQuran dan al-Hadits. Peneliti berusaha membangun sebuah konstruksi sosial akuntansi manajemen yang dilandaskan pada ayat-ayat al-Quran dan hadits Nabi SAW.

\section{HASIL DAN PEMBAHASAN}

\section{Sejarah Akuntansi Manajemen Syariah}

Sejarah tentang akuntansi manajemen syariah di Indonesia tidak bisa dipisahkan dari eksistensi akuntansi syariah, dan sejarah pengakuan dan perkembangan perbankan syariah di Indonesia. Perjuangan cukup lama agar pengakuan perbankan berbasis syariah bisa diterima pemerintah. Menurut Harahap, dkk (2010) dengan dikeluarkannya Undang-Undang No. 10 Tahun 1998 Tentang Perubahan Undang-Undang No. 7 Tahun 1992 Tentang Perbankan serta dikeluarkannya Fatwa Bunga Bank Haram dari Majelis Ulama Indonesia (MUI) tahun 2003 banyak bank-bank yang menjalankan prinsip syariah, ada yang melakukan konversi dari konsep konvensional menjadi syariah. Ada bank konvensional membuka cabang syariah dan berdirinya Bank Perkreditan Rakyat Syariah, karena bank syariah telah membuktikan memiliki berbagai keunggulan dalam mengatasi dampak krisis ekonomi yang baru lalu serta mempunyai potensi pasar yang cukup besar, mengingat mayoritas penduduk Indonesia adalah muslim dan masih banyak di kalangan umat Islam yang enggan berhubungan dengan pihak bank yang menggunakan sistem ribawi.

\section{Dasar Akuntansi Manajemen Syariah}

Islam memproklamirkan agama yang rohmatan lil 'alamin, artinya memberikan kemanfaatan bagi siapapun dimanapun. Dasar hukum dalam akuntansi manajemen syariah adalah al-Quran, hadits, dan ijtihad. Ijtihad terbagi dua yakni ijtihad sebagai sistem dan ijtihad dari produk hukum.

Akuntansi manajemen syariah tidak bisa lepas dari akuntansi syariah. Dari sisi ilmu pengetahuan, akuntansi adalah ilmu informasi yang mencoba mengkonversi 
bukti dan data menjadi informasi dengan cara melakukan pengukuran atas berbagai transaksi dan akibatnya yang dikelompokkan dalam account, perkiraan atau pos keuangan seperti aktiva, utang, modal, hasil, biaya, dan laba (Gamal, 2007)

Menurut, Toshikabu Hayashi dalam tesisnya yang berjudul "On Islamic Accounting", akuntansi barat (konvensional) memiliki sifat yang dibuat sendiri oleh kaum kapital dengan berpedoman pada filsafat kapitalisme, sedangkan dalam akuntansi syariah ada "meta rule" yang berasal diluar konsep akuntansi yang harus dipatuhi, yaitu hukum syariah yang berasal dari Tuhan, yang bukan ciptaan manusia, dan akuntansi Islam sesuai dengan kecenderungan manusia yaitu "hanief" yang menuntut agar perusahaan juga memiliki etika dan tanggung jawab sosial, bahkan ada pertanggungjawaban di akhirat, dimana setiap orang akan mempertanggungjawabkan tindakannya di hadapan Tuhan yang memiliki akuntan sendiri (malaikat Rakib dan Atid) yang mencatat semua tindakan manusia bukan saja di bidang ekonomi, tetapi juga bidang sosial-masyarakat dan pelaksanaan hukum syariah lainnya. Dari uraian diatas dapat disimpulkan bahwa konsep akuntansi dalam Islam jauh lebih dahulu dari konsep akuntansi konvensional, dan bahkan Islam telah membuat serangkaian kaidah yang belum terpikirkan oleh pakar-pakar akuntansi konvensional.

Berikut merupakan dasar akuntansi manajemen syariah yaitu:

a. Surat al-Baqarah ayat 282

"Hai orang-orang yang beriman, apabila kamu bermuamalah tidak secara tunai untuk waktu yang ditentukan, hendaklah kamu menuliskannya. Dan hendaklah seorang penulis diantara kamu menuliskannya dengan benar. Dan janganlah penulis enggan menuliskannya sebagaimana Allah telah mengajarkannya, maka hendaklah ia menulis, dan hendaklah orang yang berhutang itu mengimlakkan (apa yang akan ditulis itu), dan hendaklah ia bertakwa kepada Allah Tuhannya, dan janganlah ia mengurangi sedikitpun daripada hutangnya".

b. Surat asy-Syu'ara ayat $181-184$

"Sempurnakanlah takaran dan janganlah kamu termasuk orang-orang yang merugikan dan timbanglah dengan timbangan yang lurus. Dan janganlah kamu merugikan manusia pada hak-haknya dan janganlah kamu merajalela di muka bumi dengan membuat kerusakan dan bertakwalah kepada Allah yang telah menciptakan kamu dan umat-umat yang dahulu."

Kebenaran dan keadilan dalam mengukur (menakar) tersebut menyangkut pengukuran kekayaan, utang, modal pendapatan, biaya, dan laba perusahaan, sehingga seorang akuntan wajib mengukur kekayaan secara benar dan adil.

c. Surat al-Hujuraat ayat 6

"Hai orang-orang yang beriman, jika datang kepadamu orang fasik membawa suatu berita, maka periksalah dengan teliti, agar kamu tidak menimpakan suatu musibah kepada suatu kaum tanpa mengetahui keadaannya yang menyebabkan kamu menyesal atas perbuatanmu itu."

Ayat diatas menerangkan, untuk mengukur kekayaan secara benar dan adil, maka perlu adanya fungsi auditing. Dalam Islam, fungsi auditing ini disebut "tabayyun" 


\section{d. Surat al-Israa' ayat 35}

"Dan sempurnakanlah takaran apabila kamu menakar, dan timbanglah dengan neraca yang benar. Itulah yang lebih utama (bagimu) dan lebih baik akibatnya."

Ayat diatas menjelaskan bahwa sesuai dengan perintah Allah dalam alQuran, kita harus menyempurnakan pengukuran di atas dalam bentuk pospos yang disajikan dalam Neraca. Sehingga kaidah akuntansi dalam konsep Islam dapat didefinisikan sebagai kumpulan dasar-dasar hukum yang baku dan permanen, yang bersumber dari syariah Islam dan dipergunakan sebagai aturan oleh seorang akuntan dalam pekerjaannya, baik dalam pembukuan, analisis, pengukuran, pemaparan, maupun penjelasan, dan menjadi pedoman dalam menjelaskan suatu kejadian atau peristiwa.

Dasar hukum dalam akuntansi Syariah bersumber dari al-Quran, Sunah Nabawiyyah, Ijma (kesepakatan para ulama), Qiyas (persamaan suatu peristiwa tertentu), dan Uruf (adat kebiasaan) yang tidak bertentangan dengan Syariah Islam. Kaidah-kaidah akuntansi dalam Islam, memiliki karakteristik khusus yang membedakan dari kaidah akuntansi konvensional. Kaidahkaidah akuntansi Syariah sesuai dengan norma-norma masyarakat Islami, dan termasuk disiplin ilmu sosial yang berfungsi sebagai pelayan masyarakat pada penerapan akuntansi tersebut.

e. Surat An Nahl ayat 89

“..... Dan Kami turunkan kepadamu Al Kitab (Al Quran) untuk menjelaskan segala sesuatu dan petunjuk serta rahmat dan kabar gembira bagi orang-orang yang berserah diri."

Dalam kaidah ushl fiqh dikatakan bahwa: "hukum asal dari sesuatu (muamalah) adalah mubah sampai ada dalil yang melarangnya “. Keluasan kaidah ini membuka ruang bagi para manajer dalam menentukan aspek sosial yang bisa dimplementasikan dalam akuntansi manajemen syariah.

\section{Akuntansi Manajemen Syariah dan Konstruksi Sosial}

Kajian akuntansi manajemen syariah tidak bisa lepas dari kajian akuntansi syariah. Akuntansi manajemen Syariah memilik fungsi untuk mengidentifikasi, mengumpulkan, mengukur, mengklasifikasikan, dan melaporkan informasi, yang bermanfaat bagi pengguna internal dalam merencanakan, mengendalikan, dan membuat keputusan. Bagian integral dari manajemen yang berkaitan dengan proses identifikasi penyajian dan interpretasi/ penafsiran atas informasi yang berguna untuk merumuskan strategi, proses perencanaan, pelaksanaan, pengendalian, pengambilan keputusan, dan perlindungan atas.

Menurut Belkoui (2001), akuntansi merupakan anak dari budaya masyarakat dimana akuntansi itu dipraktikan, lebih jauh dikemukakan bahwa nilai-nilai masyarakat mempunyai peran besar dalam mempengaruhi bentuk akuntansinya. Hasil penelitianya menyatakan bahwa akuntansi dapat dipandang sebagai idiologi yang menjadi instrument pendukung tatanan sosial-ekonomi suatu masyarakat. Lahirnya akuntansi syariah sebagai idiologi masyarakat Islam menerapkan praktikpraktik ekonomi Islami dalam tata kehidupan sosial-ekonominya, sejalan dengan teori kolonial model yang dikemukakan oleh Gambling dan Karim (dalam Harahap, 2001) yaitu, masyarakat diharapkan melahirkan teori dan praktik ekonomi yang 
sesuai dengan idiologinya. Apabila idiologi yang dianut sebagian besar masyarakatnya adalah Islam, maka aturan yang dipakai seharusnya berakar pada syariat Islam. Dengan demikian sistem sosial, ekonomi, dan akuntansi yang diterapkan harus sesuai dengan syariat Islam (syariah). Islam memiliki syariah yang dipatuhi semua umatnya, maka wajarlah jika masyarakat Islam memiliki sistem ekonomi dan sistem akuntansi yang sesuai syariah".

Harahap (2001) mengemukakan bahwa akuntansi syariah adalah suatu bentuk akuntansi yang disusun berdasarkan pada pencapaian tujuan syariah, tujuan ekonomi Islam, serta tujuan masyarakat Islam. Hal ini digambarkan dalam suatu hubungan antara akuntansi syariah dengan masyarakat Islam yaitu, keberadaan akuntansi syariah sebagai idiologi masyarakat Islam menerapkan ekonomi Islam dalam kehidupan sosial ekonomi, dikenali dari persyaratan mendasar yang harus dipenuhi dan tujuan diselenggarakan akuntansi syariah

Persyaratan mendasar yang harus dipenuhi oleh akuntansi syariah yaitu benar (truth), sah (valid), adil (justice), dan mengandung nilai-nilai kebaikan atau ihsan (benevolence), sedangkan tujuan diselenggarakan akuntansi syariah adalah memberikan informasi secara lengkap untuk mengetahui nilai dan kegiatan ekonomi yang bertentangan dan yang diperbolehkan oleh syariah, meningkatkan kepatuhan terhadap prinsip syariah dalam semua transaksi dan kegiatan usaha, serta menentukan hak dan kewajiban pihak-pihak yang berkepentingan (terkait) dalam suatu entitas ekonomi syariah berlandaskan pada konsep kejujuran, keadilan, kebajikan, dan kepatuhan terhadap nilai-nilai dan etika bisnis Islami.

Akuntansi syariah diperlukan oleh masyarakat Islam sebagai instrument pendukung untuk menerapkan praktik ekonomi Islam dalam tata kehidupan sosial ekonominya dengan dasar pertimbangan yaitu adanya konsep kepemilikan yang diyakini oleh orang Islam bahwa harta dan kekayaan adalah milik Allah SWT, manusia hanyalah penerima amanah yang harus mempertanggungjawabkan pemanfaatannya sesuai dengan syariah, adanya konsep personal accountability yang harus dipatuhi oleh Islam dalam menjalin hubungan dengan Allah SWT (hablum minallah) dan menjalin hubungan dengan sesama manusia (hablum minannas), adanya konsep distribusi kekayaan secara adil yang harus dilaksanakan oleh orang Islam yaitu melalui mekanisme kewajiban membayar zakat.

Berdasarkan pada definisi akuntansi sebagai idiologi, Baydoun dan Willet (2000) mengungkapkan adanya perbedaan yang sangat mendasar mengenai sistem, prinsip dan kriteria akuntansi konvensional dengan akuntansi syariah, selain perbedaan sistem, prinsip, dan kriteria akuntansi syariah dibandingkan dengan akuntansi konvensional. Akuntansi syariah memiliki karakteristik unik, perbedaan yang lebih mendasar sebenarnya terletak pada kerangka konseptual yang mendasari kedua bentuk akuntansi tersebut. Kerangka konseptual akuntansi syariah, dirumuskan menggunakan pendekatan epistimologi Islam, sedangkan kerangka konseptual akuntansi konvensional dirumuskan menggunakan pendekatan epistimologi kapitalis. Penjelasannya secara mendalam mengenai kerangka konseptual syariah yang dirumuskan menggunakan pendekatan epistimologi Islam disajikan dalam uraian mengenai akuntansi syariah dalam konteks epistimologi Islam (Asrori, 2002). 
Motivasi para pakar dan akademisi akuntansi terutama dari kalangan orangorang Muslim guna mengkaji dan mengembangkan akuntansi syariah semakin meningkat. Setelah mengetahui beberapa peneliti (Gray, 1988; Perera, 1989; Hamid et al., 1993; Baydoun dan Willet, 1994) yang menguji hubungan antara budaya, religi dan akuntansi, menyatakan bahwa budaya secara umum dan Islam secara khusus mempengaruhi bentuk-bentuk akuntansinya. Sebagaimana dikemukakan oleh Gaffikin dan Triyuwono (1996) akuntansi adalah refleksi dari sebuah realitas yang idealnya dibangun dan dipraktikkan berdasarkan nilai-nilai dan etika. Nilai-nilai dan etika orang Muslim adalah syariah, maka alternatif terbaik pengembangan akuntansi syariah adalah menggunakan pemikiran yang sesuai dengan syariah (Asrori, 2002)

Lebih dari satu dekade yang lalu Francis (1990) telah mencoba menarik perhatian para akuntan agar melihat akuntansi tidak hanya sekedar sebagai angkaangka yang mencerminkan realitas ekonomi semata, akan tetapi melihat juga akuntansi sebagai praktik moral dan sosial. Akuntansi manajemen syariah harus mampu meningkatkan kontruksi aspek sosial dalam segala tingkatan dengan memasukan aspek sosial didalam aktifitasnya, antara lain:

a. Dari hasil laporan akuntansi, top manajemen harus mampu mengambil keputusan dalam ranah sosial terkait kebijakanya dalam menerapkan strategi perusahaan. Islam mengajarkan bahwa umat terbaik adalah yang mampu memberikan manfaat bukan hanya pada perusahan, tetapi pada masyarakat lingkungan sekitar maupun konsumen, misalnya dalam penyusunan anggaran, ekspansi usaha, diversifikasi produk, maupun kebijakan investasi lainnya. Rasulullah SAW bersabda, "Sebaik-baik manusia adalah yang paling bermanfaat bagi manusia" (HR. Ahmad, ath-Thabrani, ad-Daruqutni. Hadits ini dihasankan oleh al-Albani di dalam Shahihul Jami', no: 3289).

b. QS. Al-Isra ayat 7 sendiri"

"Jika kalian berbuat baik, sesungguhnya kalian berbuat baik bagi diri kalian

Seorang pemimpin yang mampu memberikan manfaat kepada siapapun maka dikategorikan sebagai umat terbaik. Memberikan manfaat kepada orang lain, maka manfaatnya akan kembali untuk kebaikan diri kita sendiri. Apabila dikaji secara terperinci dan mendalam dalam al-Qur'an, maka kita akan menafsirkan ayat tersebut dengan menyimpulkan bahwa kebaikan yang kita lakukan kepada orang lain dalam hal ini diluar perusahaan kita, sesungguhnya adalah dalam rangka mencari ridlo Allah untuk kebesaran diri para pemimpin, pemilik modal maupun anggota perusahaan itu sendiri.

c. QS. Al- Qashash ayat 73

"Supaya kamu mencari sebagian dari karuniaNya"

Manajer Produksi dalam menganalisis membutuhkan data informasi mengenai rincian biaya Cost of good sold atau harga pokok produksi seperti total biaya produksi, biaya per unit produk, beban tenaga kerja langsung, serta biaya overhead lainnya yang secara langsung berperan dalam proses produksi. Dalam pandangan islam sistem produksi dalam suatu negara harus dikendalikan oleh kriteria objektif dan subjektif; kriteria yang objektif akan tercermin dalam bentuk kesalehan sosial yang dapat diukur dari segi uang, 
dan kriteria subjektif dalam bentuk kesalehan sosial yang dapat diukur dari segi etika ekonomi berdasarkan al-Qur'an, Sunnah dan Ijtihad.

d. QS. Ar-Rum ayat 23

"Dan usahamu mencari bagian dari karuniaNya"

Proses produksi memiliki peran yang sangat penting dalam memakmurkan kehidupan suatu bangsa dan taraf hidup manusia, al-Qur'an membenarkan umat Islam untuk terus berjuang secara sungguh-sungguh dan terus meningkatkan keadaan sosial dan ekonominya dengan cara meningkatkan tehnik produksi.

e. Q.S. Al Hadid ayat 7

"Berimanlah kamu kepada Allah dan Rasul-Nya dan nafkahkanlah sebagian dari hartamu yang Allah telah menjadikan kamu menguasainya. Maka orang-orang yang beriman di antara kamu dan menafkahkan (sebagian) dari hartanya memperoleh pahala yang besar"

Dalam sistem produksi Islam konsep kesejahteraan ekonomi digunakan dengan cara yang lebih luas. Menurut Rahman (1995), dalam bukunya Doktrin Ekonomi Islam, konsep kesejahteraan ekonomi Islam terdiri dari bertambahnya pendapatan yang diakibatkan oleh meningkatnya produksi dari hanya barang-barang yang berfaedah melalui pemanfaatan sumbersumber daya secara maksimum baik manusia maupun benda, demikian juga melalui ikut sertanya jumlah maksimum orang dalam proses produksi. Dengan demikian, perbaikan sistem produksi dalam Islam tidak hanya berarti meningkatnya pendapatan, yang dapat diukur dari segi uang, tetapi juga perbaikan dalam memaksimalkan terpenuhinya kebutuhan kita dengan usaha minimal tetapi tetap memerhatikan tuntunan perintah-perintah Islam tentang konsumsi juga kesejahteraan sosial.

Agama Islam mengajarkan manusia memproduksi sesuatu bukanlah sekedar untuk dikonsumsi sendiri atau dijual ke pasar. Dua motivasi itu belum cukup karena masih terbatas pada fungsi ekonomi. Islam menekankan bahwa setiap kegiatan produksi harus pula mewujudkan fungsi sosial. Agar mampu mengemban fungsi sosial seoptimal mungkin, kegiatan produksi harus melampaui surplus untuk mencukupi kebutuhan konsumtif dan meraih keuntungan finansial, sehingga bisa berkontribusi kehidupan sosial. Melalui konsep ini, kegiatan produksi harus bergerak di atas dua garis optimalisasi. Optimalisasi pertama adalah mengupayakan berfungsinya sumber daya insani ke arah pencapaian kondisi full employment (tanpa pengangguran), dimana setiap orang menghasilkan karya kecuali mereka yang udzur syar'i (sakit atau lumpuh). Optimalisasi kedua memproduksi berdasarkan skala prioritas yaitu kebutuhan primer (dharuriyyat), lalu kebutuhan sekunder (hajiyyat) dan kebutuhan tersier (tahsiniyyat) secara proporsional. Tentu saja dalam memproduksi itu harus memastikan hanya memproduksi barang dan jasa yang halal dan bermanfaat buat masyarakat (halalan thayyiban) (Amri, 2015)

f. QS. Yunus ayat 55

"Ingatlah, sesungguhnya kepunyaan Allah apa yang ada di langit dan di bumi. Ingatlah, sesungguhnya janji Allah itu benar, tetapi kebanyakan mereka tidak mengetahui (nya)" 
Manajer Keuangan dalam akuntansi manajemen membutuhkan informasi terkait dengan aktifitas keuangan perusahaan seperti pendanaan modal kerja, biaya, yang harus benar-benar dipahami oleh manajer keuangan. Mereka harus memahami modal kerja yang dibutuhkan oleh perusahaan, tingkat pengembalian investasi, tingkat pengembalian modal, rasio keuangan, dan lainnya. Dalam sejarah Islam, Rasul SAW menanamkan nilai-nilai peradaban yang tinggi dan akhlak mulia, dalam mengelola keuangan, tidak seperti saat kapitalisme menguasai setiap perilaku manusia.

g. QS. At-taubah ayat 34

“.....orang-orang yang menyimpan emas dan perak dan tidak menafkahkannya pada jalan Allah, maka beritahukanlah kepada mereka, (bahwa mereka akan mendapat) siksa yang pedih"

Agama Islam mengajarkan manusia untuk mempelajari ilmu tata kelola keuangan dari sumber al-Quran dan al-Hadits.

h. QS. Al-Baqarah ayat 188

"Dan janganlah sebahagian kamu memakan harta sebahagian yang lain di antara kamu dengan jalan yang bathil, dan (janganlah) kamu membawa (urusan) harta itu kepada hakim, supaya kamu dapat memakan sebahagian daripada harta benda orang lain itu dengan (jalan berbuat) dosa, padahal kamu mengetahui"

Penciptaan alam semesta dan seisinya ini merupakan rahmat yang Allah SWT yang diberikan kepada manusia, jangan sampai manusia menggunakannya dalam jalan-jalan kebathilan.

i. QS. Al-Hadid ayat 7

"Berimanlah kamu kepada Allah dan Rasul-Nya dan nafkahkanlah sebagian dari hartamu yang Allah telah menjadikan kamu menguasainya. Maka orang-orang yang beriman diantara kamu dan menafkahkan (sebagian) dari hartanya memperoleh pahala yang besar"

Manajer keuangan dalam pengelolaan keuangan harus menaati aturan undang-undang keuangan syariah. Sehingga mereka memahami batasan halalharam yang menjadi kode etik dalam berekonomi. Kaidah hukum Islam menyatakan bahwa segala sesuatu hukum asalnya adalah boleh sampai ada nas-nas yang mengharamkannya.

j. QS. Al-Baqarah ayat 188

"Dan janganlah sebahagian kamu memakan harta sebahagian yang lain di antara kamu dengan jalan yang bathil dan (janganlah) kamu membawa (urusan) harta itu kepada hakim, supaya kamu dapat memakan sebahagian daripada harta benda orang lain itu dengan (jalan berbuat) dosa, padahal kamu mengetahui"

Batasan haram yang sangat jelas dalam bermuamalah khususnya dalam hal mengelola keuangan adalah la ta'kulû amwâlakum baynakum bi al-bâthil (tidak memperoleh harta dengan cara tidak benar). Sementara al-Sunah juga memberikan rambu-rambu lâ dharar wa lâ dhirâr (jangan sampai merugikan diri sendiri maupun orang lain). Berdasarkan HR. Ibnu Majah dari Said al-Khudri menyatakan bahwa ketika rambu-rambu di atas diterjang misalnya melalui praktek riba maka berakibat pada melemahnya ekonomi itu sendiri sebut saja harga komoditas melambung tinggi, jumlah hutang berlipat ganda, hingga penimbunan untuk memainkan harga pasar. 
k. QS. Ad-Dhuha ayat 11

"Dan terhadap nikmat Rabbmu, maka hendaklah kamu menyebut-nyebutnya (dengan bersyukur)" Allah memerintahkan umatnya untuk menceritakan apa yang akan kita lakukan, sedang maupun yang sudah selesai dari kegiatan kita"

Manajer Pemasaran membutuhkan data informasi seluruh komponen biaya terkait dalam penetapan harga jual produk, penentuan sistem penjualan secara kredit atau tunai, beban komisi penjualan, marketing fee, serta informasi nilai discount untuk produk tertentu dalam rangka peningkatan volume penjualan. Menurut prinsip syariah, kegiatan pemasaran harus dilandasi semangat beribadah kepada Allah SWT berusaha semaksimal mungkin untuk kesejahteraan bersama, bukan untuk kepentingan golongan apalagi kepentingan sendiri. Dalam ayat diatas, ada kata "fahaddits" yang berarti pesan pengulangan kepada kita daam melakukan kegiatan ekonomi dalam hal ini salah satunya adalah proses pemasaran.

\section{SIMPULAN}

Akuntansi manajemen secara ideal harus dibangun dan dipraktikkan berdasarkan nilai sosial, sehingga informasi yang dipancarkan juga bernuansa sosial, dan pada akhirnya keputusan-keputusan ekonomi yang diambil oleh top management maupun middle management berdasarkan atas nilai sosial yang mendorong terciptanya realitas ekonomi dan bisnis yang mengarah pada kesalehan sosial yang berkemakmuran dan berkeadilan.

Nilai-nilai universal sesungguhnya sudah ada dalam al-Quran dan al-Hadits namun semangat untuk menggali harus terus menerus ditingkatkan dalam rangka memenuhi tugas manusia di dunia sebagai kholifah fil ardli (manusia sebagai utusan tuhan di bumi).

\section{DAFTAR PUSTAKA}

Amir, Amri. (2015). Ekonomi dan Keuangan Islam. Jambi: Pustaka Media.

Asrori. (2002). Akuntansi Syariah Bidang Baru Akuntansi dalam Konteks

Epistemologis Islam. Jurnal Ekonomi dan Manajemen Vol 11, No. 2, 2002.

Aziz, Fathul Aminudin. (2017). Manajemen dalam Perspektif Islam. Cilacap: Pustaka ElBayan.

Bahri, Syaiful. (2016). Pengantar Akuntansi Berdasarkan SAK ETAP dan IFRS. Yogyakarta: Penerbit Andi.

Baydoun and Willet. (2000). Islamic Corporate Report. Abacus, Volume 36. No. 1.

Belkoui, Ahmed Riahi. (2001). Teori Akuntansi. Jakarta: Salemba Empat.

Francis, Jere R. (1990). After Virtue? Accounting as Moral and Discursive Practice. Accounting, Auditing, and Accountability Journal 3 (3): 5-17. 
Gamal, M. (2007). Mengenal Prinsip Akuntansi Syariah (Ringkasan Sosial Ekonomi Islam).

Hadi, Sutrisno. (1990). Metodologi Research. Yogyakarta: Fakultas Psikologi UGM.

Harahap, dkk. (2010). Akuntansi Perbankan Syariah: PSAK Syariah Baru. Edisi Cetakan $I V$. Jakarta: LPFE Usakti.

Hariadi, Bambang. (2002). Akuntansi Manajemen. Edisi 1, Cetakan Pertama. Yogyakarta: BPFE.

Hayashi, Toshikabu. (1989). On Islamic Accounting. Jakarta: Salemba Empat.

Mulyadi. (2001). Akuntansi Manajemen; Konsep, Manfaat, dan Rekayasa. Jakarta: Salemba Empat.

Rahman, Afzalur. (1995). Doktrin Ekonomi Islam. Yogyakarta: Dana Bhakti Wakaf. 